\title{
Dermatological manifestations in autoimmune thyroid disorders
}

\author{
N Nagaraj , AL Balaji, S Singla, M Prakash \\ From International Conference for Healthcare and Medical Students 2011 \\ Dublin, Ireland. 4-5 November 2011
}

\section{Introduction}

Thyroid hormone deficiency causes skin changes including thickening, pruritis, alopecia, xerosis, nail changes and dermopathy. These manifestations depend on various factors like duration of disease, treatment and follow-up. We conducted this study to show the cutaneous manifestations of auto-immune thyroid disease (AITD) as a marker for diagnosis and treatment.

\section{Methods}

We examined 400 consecutive patients presenting to the endocrinology/dermatology department of a tertiary care referral hospital in Bangalore who were diagnosed with AITD between the periods from $06 / 07-06 / 10$ on an outpatient basis. Detailed history and physical examination including cutaneous examination was done. Mean follow up was done for the period of 6 months for the cutaneous manifestations.

\section{Results}

400/1020 (39.2\%) patients presented with cutaneous manifestations with AITD. This comprised of 42(10.5\%) males and $358(89.5 \%)$ females. The cutaneous presentations were nail changes(336), dermopathy(48), urticaria(114), vitiligo (74), alopecia(90), and pruritis(242). The other co-morbid conditions associated were diabetes(160), hypertension (190), psoriasis(38), addisons disease(9) and PCOS (93).

\section{Conclusions}

The study shows the cutaneous manifestations of AITD, which should be evaluated completely and followed-up with regular thyroid function tests and thyroid hormone replacement. Discontinuation of thyroid hormone therapy may result in recurrence. The cutaneous manifestations can also be used as a diagnostic marker for AITD. In a

Rajiv Gandhi University of Health Sciences, India country like India, thyroid diseases go unnoticed mainly due to reduced incidence previously and lack of awareness among the patient population. AITD is not easily diagnosed and cutaneous manifestations shall result in early diagnosis and treatment for AITD and other thyroid diseases.

Published: 9 July 2012

doi:10.1186/1753-6561-6-S4-039

Cite this article as: Nagaraj et al:: Dermatological manifestations in autoimmune thyroid disorders. BMC Proceedings 2012 6(Suppl 4):O39.
Submit your next manuscript to BioMed Central and take full advantage of:

- Convenient online submission

- Thorough peer review

- No space constraints or color figure charges

- Immediate publication on acceptance

- Inclusion in PubMed, CAS, Scopus and Google Scholar

- Research which is freely available for redistribution

Submit your manuscript at www.biomedcentral.com/submit
() Bïomed Central (c) 2012 Nagaraj et al; licensee BioMed Central Ltd. This is an Open Access article distributed under the terms of the Creative Commons Attribution License (http://creativecommons.org/licenses/by/2.0), which permits unrestricted use, distribution, and reproduction in any medium, provided the original work is properly cited. 